\title{
Fluoroscopic Detection of Ventral Wall Violation during C2 Intralaminar Screw Insertion: A Descriptive Study
}

\section{ABSTRACT}

Introduction: The C2 (second cervical) laminar screws were considered for rigid fixation of the axis because the use of pars or pedicle screws posed a risk to the vertebral artery with C2. Though considered to be a relatively safe method, ventral spinal canal violations have been reported in laminar screws fixations. Fluoroscopy-based image guidance may increase the accuracy and safety of the technique.

Aim: To report the use of fluoroscopy technique in the detection of ventral wall violation during $\mathrm{C} 2$ intralaminar screw insertion.

Materials and Methods: This descriptive study reports seven dry axis vertebrae from the adult south Indian population for which fluoroscopic analysis was done from January 2013 to December 2013. True lateral views were taken before and after applying a vertical line of barium paint on the ventral surface of the lamina at two points: at the centre of the lamina and close to the facet joints at the face to-laminar junction.

Results: In the total seven dry axis vertebrae analysed, the mean ratio of the distance from the spinolaminar junction to the barium line (drawn on the ventral surface of the lamina just next to face to laminar junction) to the distance between the spinolaminar junction and uppermost part of inferior articular facet of C2 vertebrae was $0.465 \pm 0.0389 \mathrm{~mm}$.

Conclusion: Even though considered a relatively safer technique, laminar cortical violations have been reported in $\mathrm{C} 2$ translaminar screw fixations. Fluoroscopy-based imaging guidance can improve the accuracy of C2 translaminar screw insertion, as this technology provides real-time imaging during the process of screw insertion and helps in accurate screw sizing.

\section{INTRODUCTION}

The C2 translaminar screw, brought into use by Wright in 2004, has gained popularity for these reasons: the large size of the C2 lamina, there is rigid fixation of the axis, and has low risk of injuring the vertebral artery [1,2]. This technique has now been compared with other available methods and biomechanical comparability has been established [3,4]. Although considered to be a relatively safer method, laminar violations have been reported in some cases [1,2]. Translaminar screws which may transgress the ventral cortical wall of the lamina can lead to debilitating complications. Also, in recent times, the reliability of intraoperative plain radiographs in detecting violations of C2 intralaminar screws has been called into question [5]. The advent of the fluoroscopy-based image-guidance technique has helped in safe and precise spinal instrumentation at all vertebral levels, including placement into C2 pars, C2 pedicle, the odontoid, and the C1-C2 transarticular junction [6-12]. In past published literature, one report on fluoroscopy-based image guidance usage for the placement of C2 laminar screws is available [13]. Hence, this descriptive study was done to report the use of fluoroscopy technique in the detection of ventral wall violation during C2 intralaminar screw insertion.

\section{MATERIALS AND METHODS}

This descriptive study was conducted at the Human Anatomy Department, St. Johns Medical College, Bangalore, Karnataka, India, from January 2013 to December 2013.

Inclusion criteria: A total of seven dry axis vertebrae from the adult south Indian population (anatomical specimen) were included in this study.

Exclusion criteria: Those specimens with deformities, defects or tumours were excluded from the study.
True lateral views were taken before and after applying a vertical line of barium paint on the ventral surface of lamina at two points: at the centre of the lamina and close to the facet joints at the face to-laminar junction using Philips brilliance machine. Distances from the highest point of the inferior articular facet (distance B) and the spinolaminar line (distance $A$ ) to the vertical barium line adjacent to the facet joint were measured [Table/Fig-1]. A ratio $A /(A+B)$ was measured. A horizontal line of barium paint was marked on the ventral surface of the lamina. The fluoroscopic arm was tilted till this barium line was seen as a point (co-axial view) [Table/Fig-2].
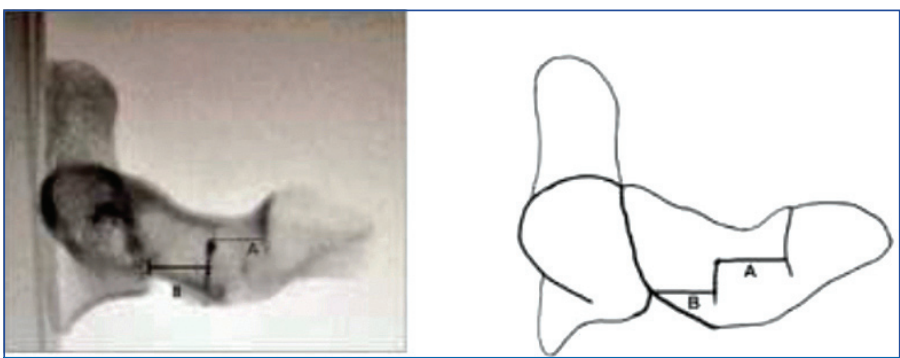

[Table/Fig-1]: Lateral View with barium applied at the ventral surface at mid lamina and close to the facet joint. $A=$ spinolaminar line to the vertical barium line; $B=$ from the highest point of the inferior articular facet o the vertical barium line

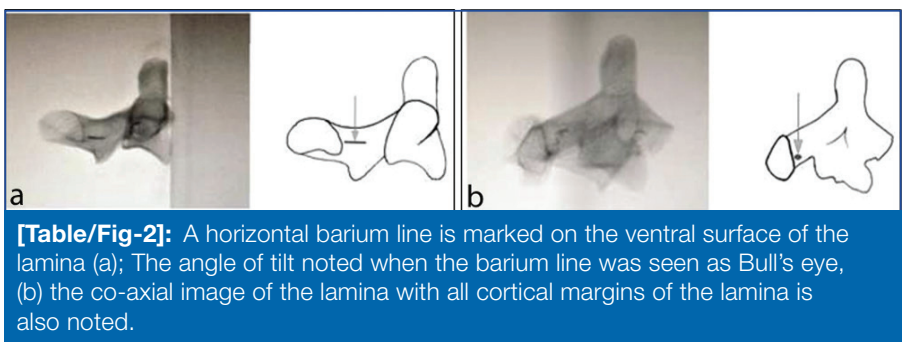




\section{STATISTICAL ANALYSIS}

The statistical analysis was done using Microsoft (MS) Excel and the actual dimensions of the vertebrae has been tabulated.

\section{RESULTS}

The mean ratio of the distance from the spinolaminar junction to the barium line (drawn on the ventral surface of the lamina just next to the faucet laminar junction) to the distance between the spinolaminar junction and uppermost part of the inferior articular facet of C2 vertebrae was $0.465 \pm 0.0389 \mathrm{~mm}$ [Table/Fig-3]. Out of the 14 laminae studied, we were able to see a vertical faucet laminar line in $10(71.48 \%)$ specimens. In 4 of 10 cases, the barium line corresponded to the face to-laminar line. In the remaining 6 of 10 cases, the face to-laminar line was just dorsal to the barium line. Vertical face to-laminar line corresponding to the barium line (A) and dorsal to the barium line (B) [Table/Fig-4].

\begin{tabular}{|l|c|c|c|c|c|c|c|c|}
\hline No. & $\begin{array}{c}\text { Right-A* } \\
(\mathrm{mm})\end{array}$ & $\begin{array}{c}\text { Right-B } \\
(\mathrm{mm})\end{array}$ & $\begin{array}{c}\text { Right } \\
\mathrm{A} / \\
(\mathrm{A}+\mathrm{B})\end{array}$ & $\begin{array}{c}\text { Left-A } \\
(\mathrm{mm})\end{array}$ & $\begin{array}{c}\text { Left-B } \\
(\mathrm{mm})\end{array}$ & $\begin{array}{c}\text { Left } \\
\mathbf{A} / \\
(\mathrm{A}+\mathrm{B})\end{array}$ & $\begin{array}{c}\text { Right } \\
\text { angle } \\
(\text { degree })\end{array}$ & $\begin{array}{c}\text { Left } \\
\text { angle } \\
(\text { degree })\end{array}$ \\
\hline 1 & 0.93 & 1.17 & 0.44 & 1.02 & 1.11 & 0.47 & 41 & 47 \\
\hline 2 & 1.08 & 0.87 & 0.55 & 1.02 & 0.9 & 0.53 & 42 & 37 \\
\hline 3 & 1.2 & 1.45 & 0.45 & 1.23 & 1.45 & 0.46 & 45 & 29 \\
\hline 4 & 1.32 & 1.54 & 0.46 & 1.36 & 1.39 & 0.49 & 43 & 38 \\
\hline 5 & 0.92 & 1.36 & 0.41 & 1.11 & 1.39 & 0.44 & 53 & 36 \\
\hline 6 & 1.11 & 1.2 & 0.47 & 1.02 & 1.29 & 0.44 & 47 & 40 \\
\hline 7 & 1.23 & 1.2 & 0.50 & 1.21 & 1.14 & 0.51 & 44 & 37 \\
\hline
\end{tabular}

[Table/Fig-3]: Fluoroscopic analysis of second cervical (C2) vertebrae. "Distances from the highest point of the inferior articular facet (b) and the spinolaminar line (a) to the vertical barium line adjacent to the facet joint

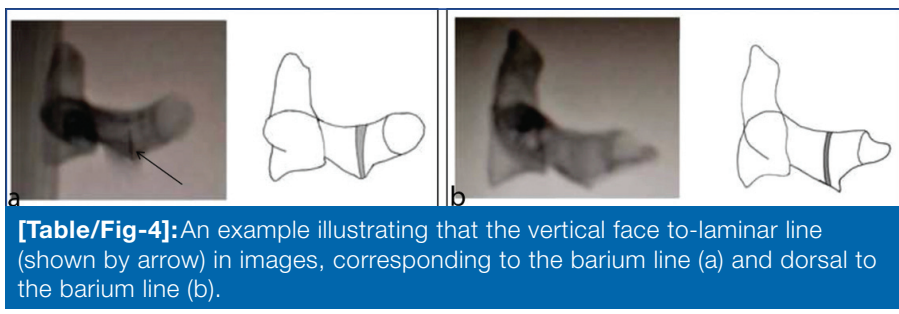

\section{DISCUSSION}

This current study showed that placing C2 intralaminar screws under fluoroscopic guidance can detect ventral wall violation. This can be used intraoperatively to prevent the ventral wall violation that can occur during C2 intralaminar screw insertion. The technique, as defined by Wright NM and in other studies, is based completely on anatomical landmarks with or without the use of intraoperative fluoroscopy $[1-4,14]$. The dorsal laminar breach can be easily identifiable intraoperatively by visual inspection. But this is not possible for a ventral breach, which is important to confirm safe intralaminar screw placement. Hence, a fluoroscopy-guided approach can help in the detection intraoperatively. This usage has been demonstrated by this study in dry anatomical specimens. This procedure can be replicated intraoperatively by the surgeon.

Lehman RA et al., did a study to find the use of intraoperative plain radiographs in identifying violations of $\mathrm{C} 2$ intralaminar screws insertion in cadaveric models and showed that the overall accuracy rate was only $77.4 \%$ [5]. The authors also alerted that in cases of both C2 intralaminar screws were out, the accuracy was reduced to $63.9 \%$. Thereby suggesting that in cases of bilateral screw perforations, plain radiographs cannot be relied on to detect the violation. Wang MY did a study on CT images of 59 intralaminar screws in 30 patients and established the partial dorsal laminar breach in 11 patients and violation of the spinal canal in one patient [15]. C2 translaminar screw placement has gained popularity as a new alternative for rigid fixation to the axis. Although, it is considered to be a relatively safe technique, laminar cortical violations have been reported and its safety profile has not been validated by longterm studies.

Based on the present study, the authors proposed that if the tip of the screw after placement is just dorsal to the $50 \%$ point between the spinolaminar line and superior most point of the inferior articular facet of the axis vertebra, one can safely rule out a ventral cortex violation. The need for a true lateral view cannot be over-emphasised in this regard. The vertical face-laminar line seen in some $\mathrm{X}$-rays $10 / 14(71.4 \%)$ is also a good indicator as it is seen just dorsal (6/10, $60 \%)$ or corresponds $(4 / 10,40 \%)$ to the barium line just next to the facet joint. Alternatively, an oblique view of the axis vertebra can be taken as described in material and methods [Table/Fig-4] to have a coaxial image of the lamina. The screw can then be inserted safely within the cortical walls. However, this method can only be used with radiolucent operating table attachments. This is the first study using dry vertebrae and an objective method to effectively utilise fluoroscopy while inserting C2 translaminar screws. This can be adapted by spine surgeons on intraoperative usage.

\section{Limitation(s)}

Relatively small sample size and the procedure was done on the anatomical specimen.

\section{CONCLUSION(S)}

This study has shown that fluoroscopy-guided C2 translaminar screw fixation can improve the accuracy of fixation. This technique can provide real-time images intraoperatively and accurate placement can be achieved without ventral wall violation. Studies with large sample size and intraoperative fluoroscopic guided studies are recommended in the future following the sampling technique.

\section{REFERENCES}

[1] Wright NM. Posterior C2 fixation using bilateral, crossing C2 laminar screws: Case series and technical note. J Spinal Disord. 2004;17(2):158-62.

[2] Material C. Translaminar rigid screw fixation of the axis. Spine (Phila Pa 1976). 2005;3(5):409-14.

[3] Gorek J, Acaroglu E, Berven S, Yousef A, Puttlitz CM. Constructs incorporating intralaminar C2 screws provide rigid stability for atlantoaxial fixation. Spine (Phila Pa 1976). 2005;30(13):1513-18.

[4] Lapsiwala SB, Anderson PA, Oza A, Resnick DK. Biomechanical comparison of four $\mathrm{C} 1$ to $\mathrm{C} 2$ rigid fixative techniques: Anterior transarticular, posterior transarticular, $\mathrm{C} 1$ to $\mathrm{C} 2$ pedicle, and $\mathrm{C} 1$ to $\mathrm{C} 2$ intralaminar screws. Neurosurgery. 2006;58(3):516-20.

[5] Lehman RA, Sasso RC, Helgeson MD, Dmitriev AE, Gill NW, Rosner MR, et al. Accuracy of intraoperative plain radiographs to detect violations of intralaminar screws placed into the C2 vertebrae: A reliability study. Spine (Phila Pa 1976). 2007;32(26):3036-40.

[6] Rajasekaran S, Vidyadhara S, Ramesh P, Shetty AP. Randomized clinical study to compare the accuracy of navigated and non-navigated thoracic pedicle screws in deformity correction surgeries. Spine (Phila Pa 1976). 2007;32(2):E56-64.

[7] Rajasekaran S, Vidyadhara S, Shetty AP. Intra-operative Iso-C3D navigation for pedicle screw instrumentation of hangman's fracture: A case report. J Orthop Surg (Hong Kong). 2007;15(1):73-77.

[8] Acosta FL, Thompson TL, Campbell S, Weinstein PR, Ames CP. Use of intraoperative isocentric C-arm 3D fluoroscopy for sextant percutaneous pedicle screw placement: Case report and review of the literature. Spine J. 2005;5(3):339-43.

[9] Holly L, Foley K. Percutaneous placement of posterior cervical screws using three-dimensional fluoroscopy. Spine (Phila Pa 1976). 2006;31(5):536-40.

[10] Holly LT, Foley KT. Three-dimensional fluoroscopy-guided percutaneous thoracolumbar pedicle screw placement. Technical note. J Neurosurg. 2003;99(3 Suppl):324-29.

[11] Hott JS, Deshmukh VR, Klopfenstein JD, Sonntag VKH, Dickman CA, Spetzler $\mathrm{RF}$, et al. Intraoperative Iso-C C-arm navigation in craniospinal surgery: The first 60 cases. Neurosurgery. 2004;54(5):1131-37.

[12] Villavicencio AT, Burneikiene S, Bulsara KR, Thramann JJ. Utility of computerized isocentric fluoroscopy for minimally invasive spinal surgical techniques. J Spinal Disord Tech. 2005;18(4)(Suppl.1):369-75.

[13] Nottmeier EW, Foy AB. Placement of $C 2$ laminar screws using three-dimensional fluoroscopy-based image guidance. Eur Spine J. 2008;17(4):610-15. 
[14] Leonard JR WN. C2 Fixation with bilateral, crossing translaminar screws. J Neurosurg. 2006;104:59-63.
[15] Wang MY. Cervical crossing laminar screws: Early clinical results and complications. Neurosurgery. 2007;61(5):311-16.

\section{PARTICULARS OF CONTRIBUTORS:}

1. Professor, Department of Neurosurgery, Jawaharlal Nehru Medical College, Aligarh, Uttar Pradesh, India.

2. Associate Professor, Department of Neurosurgery, Jawaharlal Nehru Medical College, Belgaum, Karnataka, India.

3. Professor, Department of Neurosurgery, National Institute of Mental Health and Neuro-Sciences, Bangalore, Karnataka, India.

NAME, ADDRESS, E-MAIL ID OF THE CORRESPONDING AUTHOR:

Prakash Mahantshetti,

RC Nagar $2^{\text {nd }}$ Stage, Belagavi, Karnataka, India.

E-mail: drprakashsm@gmail.com
PLAGIARISM CHECKING METHODS: Jain Het al.]

- Plagiarism X-checker: Aug 31, 2021

- Manual Googling: Dec 10, 2021

- iThenticate Software: Dec 31, 2021 (10\%)
ETYMOLOGY: Author Origin

\section{AUTHOR DECLARATION:}

- Financial or Other Competing Interests: None

- Was Ethics Committee Approval obtained for this study? NA

- Was informed consent obtained from the subjects involved in the study? NA

- For any images presented appropriate consent has been obtained from the subjects.
Date of Submission: Aug 30, 2021 Date of Peer Review: Nov 27, 2021 Date of Acceptance: Dec 26, 2021 Date of Publishing: Jan 01, 2022 